\author{
EVS29 Symposium \\ Montréal, Québec, Canada, June 19-22, 2016
}

\title{
Electric Vehicle Dealership Education \& Training
}

\author{
Market Development \& Demand Issues - E25 - Education \& training
}

\author{
Manoj K. Karwa \\ Leviton Manufacturing Co., Inc. \\ 201North Service Drive, Melville, NY 1174, mkarwa@leviton.com
}

\begin{abstract}
Short Abstract
A major hurdle in the adoption and optimization of electrical vehicles is the transfer of knowledge from the dealer to the consumer. The first point of contact for most electric vehicle consumers is the dealer sales staff. Often dealerships have high turnover in sales staff and are driven to annual, quarterly and monthly sales. The majority of dealerships' focus is on closing new car sales, service and accessories. Leviton will share insights and best practices from the deployment of electrical vehicle supply equipment with four major automakers across nearly 3,000 dealerships in North America.
\end{abstract}

\section{Introduction}

Leviton is a 110 year-old privately held electrical device manufacturer. Our Canadian headquarters is in Pointe-Claire, Quebec. We provide nearly 26,000 products across 100 different countries. Our products are found in 9 out of 10 homes making us the North American leader in electrical wiring devices.

Leviton has been the primary supplier of electric vehicle supply equipment (EVSE) for four major automakers - Toyota, Honda, Kia and Ford Motor. We have been directly or indirectly involved with the infrastructure deployment of nearly 3,000 dealerships across the USA and Canada. We have derived valuable insights from this experience including dealership behavior and responsiveness to electric vehicles and associated infrastructure. Our EVSE team has trained and piloted programs with hands-on experience at major dealerships in the top electric vehicle markets throughout North America. In light of this experience, we have found an opportunity to improve the first contact of electrical vehicle consumers.

In addition to the automaker programs, we have been awarded multiple New York State and Energy Association Grants. The first public opportunity notice (PON), 2301 was a statewide deployment of networked stations in the work place. The most recent PON 3016 involves dealership education and outreach. This PON is underway and many of the insights from this program are discussed in this paper.

In general, dealerships are compensated by new car sales, service volume and accessory transactions. The dealerships are often measured based on monthly, quarterly and annual metrics. Their sales staff on occasion have high turnover and do not have the resources or motivation to educate on new technology or market trends. 


\subsection{Role of Dealership in EV Infrastructure}

Dealerships are key market actors in the successful deployment of electric vehicles and infrastructure. They hold a unique position in the electric vehicle diaspora of being the first point of contact with the consumer. Dealerships provide training and education on the vehicles, their benefits and their service or warranty agreement.. A dealership also can be a workplace where they offer electric vehicle infrastructure for their staff that drive electric vehicles. Dealerships are private enterprises and have a high level of staff turnover. Often the sales staff may move from one dealership to another.

The key stakeholders at a dealership that can influence the electric vehicle purchase include - Dealer Principle, General Manager, Manager of Finance and Insurance, Sales Manager and Technician. Each of these stakeholders may intersect with the consumer and influence their buying decisions.

\section{Sales Manager and /or Internet Sales Manager}

Sales staff may interact with you on the phone, in person or online. They should let you know if a particular electric car is available, what is the charging time, battery time or electric vehicle range. They may also go along with you on a test drive and start the negotiation and collect information. They are typically the main contact for the electric vehicle consumer.

\section{The Assistant / Sales Manager}

One level above the sales staff and is usually brought in to close the deal and discuss the numbers. Their objective is to get the deal. Depending on the size of the dealership there may be an assistant and a sales manager. Typically the final decision on vehicle price lies with the sales manager.

\section{The Finance and Insurance (F\&I) Manager}

The finance and insurance manager or F\&I manager develops the contract and financing. At this juncture the F\&I Manager may add additional options or services such as warranties or products. This may be the opportunity for the F\&I manager to offer a charging station or installation.

\section{The General Manager or Dealer Principle}

The General Manager or Dealer Principle will be the top level at the dealership. They may also make decisions on investments to electrical vehicle infrastructure. They typically interact the most with the automotive manufacturers. They may also have equity in the dealership, either as a sole owner or part of a larger group.

\section{Technician / Part \& Service staff}

Electric vehicles typically need minimum servicing - depending if they are a plug in vehicle or all electric. That being said the technician may interact with the consumer at some point and provide guidance on the required maintenance of the electric vehicle. In addition a consumer may visit the parts \& service staff to get more information or purchase a Level 2 charging station.

\subsection{Stakeholders in Electrical Vehicle Infrastructure}

Electrical vehicle infrastructure includes key stakeholders outside of the automaker ecosystem. Key participants include the electrical vehicle supply equipment manufacturer, distributor, electrician and consumer. The electric vehicle manufacture often completes stringent testing with the automaker including compatibility, measurement of optimum charge time, agency testing and field testing. The distributor may 
include electrical distribution, retail distributors or automotive parts and equipment suppliers. The electrical contractor may be part of a larger group, franchise or independent. Many of the value chain stakeholders rely on the EVSE manufacturer for training - product bulletins, video, customer service, instruction.

\subsection{Importance of Dealership Training on EV Adoption}

Based on Leviton's experience deploying 3,000 dealerships in North American from our primary and secondary research we believe there is an obstacle in electric vehicle adoption due to lack of dealership knowledge. There are many advantages of electric vehicles but without the proper education, training and incentives, it will always be easier for dealerships' staff to sell internal combustion vehicles. With no difference in commission and fewer questions to answer, the salesperson will steer their customer toward products of which they understand or have legacy experience. Information, incentives and inspiration can shift the salesperson's paradigm to place the electric vehicle within their comfort zone.

Dealerships are measured by new car sales, service volume and accessory transactions. The dealerships are often measured based on monthly, quarterly and annual metrics. Their sales staff often have high turnover and do not have the resources or motivations to educate on new technology or market trends. Training made available for dealership staff by the automakers is often lost with new staff.

Through the Center for Sustainable Energy (CSE), a non-profit organization in San Diego facilitating sustainable energy programs, an extensive survey was conducted on dealership knowledge of EVSEs. The survey was conducted in California but since that state is generally considered to be a leader in EVSE deployment we believe the study can provide valuable insights into best practices. The survey was broken into two broad categories:

1. Dealership/showroom knowledge and perceived value

2. Dealership/showroom services

Under Item 1 (dealership/showroom knowledge and perceived value), only $22 \%$ of consumers felt their dealership was very knowledgeable about "home charging." Moreover, $84 \%$ felt it was both valuable and very valuable that dealerships or salespersons be knowledgeable about "home charging". This demonstrates a gap between what a dealership knows opposed to what a consumer would like them to know. Unless you are a first-adopter, it is quite reasonable to assume you will be steered away from electric vehicles toward conventional vehicles by your salesperson.

Under Item 2 (dealership/showroom services) customers were asked the value of the dealership/salesman facilitating EVSE installation and $40 \%$ felt that it was valuable and $26 \%$ replied very valuable. However this information was only offered in $22 \%$ of the dealerships. Nearly $80 \%$ of the dealerships would have been receptive to additional hands-on training on the electric vehicle market. The market want could be met with an acceptable training regimen for the dealerships.

In the CSE study, 14,205 people responded to the questionnaire on a wide variety of subjects involving electric vehicles and infrastructure issues. Table 1 highlights that the opportunities for improvement for the dealerships, specifically the area of dealership knowledge. 
Table 1: Dealer Knowledge and Value

\begin{tabular}{|c|c|}
\hline \multicolumn{2}{|c|}{ HOW KNOWLEDGEABLE WAS DEALER? } \\
\hline Topic & Value \\
\hline $\begin{array}{l}\text { Total cost of ownership (including: } \\
\text { fuelling costs, maintenance, insurance, } \\
\text { etc.) }\end{array}$ & 3.27 \\
\hline $\begin{array}{l}\text { Electricity rates (utility specific rates } \\
\text { for PEV charging at home) }\end{array}$ & 2.51 \\
\hline $\begin{array}{l}\text { Home charging (equipment options } \\
\text { and installation costs) }\end{array}$ & 3.16 \\
\hline $\begin{array}{l}\text { 'Away from home' charging } \\
\text { (workplace, charging networks, public } \\
\text { chargers) }\end{array}$ & 2.77 \\
\hline $\begin{array}{l}\text { Government financial incentives } \\
\text { (tax credits, rebates) }\end{array}$ & 3.78 \\
\hline $\begin{array}{l}\text { Non-financial incentives/perks } \\
\text { (HOV lane access, free parking, free } \\
\text { charging stations, etc.) }\end{array}$ & 3.49 \\
\hline $\begin{array}{l}\text { Vehicle performance (range, battery } \\
\text { life, etc.) }\end{array}$ & 3.85 \\
\hline $\begin{array}{l}\text { Assistance setting up and explaining } \\
\text { PEV related 'apps' }\end{array}$ & 2.6 \\
\hline Mean of Averages & 3.18 \\
\hline
\end{tabular}

\begin{tabular}{|c|c|}
\hline \multicolumn{2}{|l|}{ VALUE ACCORDING TO CUSTOMER } \\
\hline Topic & Value \\
\hline $\begin{array}{l}\text { Total cost of ownership (including: } \\
\text { fuelling costs, maintenance, insurance, } \\
\text { etc.) }\end{array}$ & 3.96 \\
\hline $\begin{array}{l}\text { Electricity rates (utility specific rates } \\
\text { for PEV charging at home) }\end{array}$ & 3.61 \\
\hline $\begin{array}{l}\text { Home charging (equipment options } \\
\text { and installation costs) }\end{array}$ & 3.9 \\
\hline $\begin{array}{l}\text { 'Away from home' charging } \\
\text { (workplace, charging networks, public } \\
\text { chargers) }\end{array}$ & 3.68 \\
\hline $\begin{array}{l}\text { Government financial incentives } \\
\text { (tax credits, rebates) }\end{array}$ & 4.16 \\
\hline $\begin{array}{l}\text { Non-financial incentives/perks } \\
\text { (HOV lane access, free parking, free } \\
\text { charging stations, etc.) }\end{array}$ & 3.97 \\
\hline $\begin{array}{l}\text { Vehicle performance (range, battery } \\
\text { life, etc.) }\end{array}$ & 4.2 \\
\hline $\begin{array}{l}\text { Assistance setting up and explaining } \\
\text { PEV related 'apps' }\end{array}$ & 3.01 \\
\hline Mean of Averages & 3.81 \\
\hline
\end{tabular}

\begin{tabular}{|l|l|}
\hline \multicolumn{2}{|l|}{ KEY: } \\
\hline Not at all knowledgeable & 1 \\
\hline Not very knowledgeable & 2 \\
\hline Unsure & 3 \\
\hline Knowledgeable & 4 \\
\hline Very knowledgeable & 5 \\
\hline
\end{tabular}

\begin{tabular}{|l|l|}
\hline KEY: & \multicolumn{1}{|l|}{} \\
\hline Not at all valuable & 1 \\
\hline Not very valuable & 2 \\
\hline Unsure & 3 \\
\hline Valuable & 4 \\
\hline Very valuable & 5 \\
\hline
\end{tabular}

Data configured from the Center for Sustainable Energy

Plug in Hybrid Electric Vehicles (PHEV) have internal combustion engines (ICE). The maintenance requirements of PHEVSs are comparable to standard fossil fuelled based vehicles. PHEVs have electrical systems that will require minimal scheduled maintenance which may include the lead acid battery (separate from the Lithium Ion battery), electrical accessories and electronics. The use of regenerative braking greatly reduces the service and repair required with the brake systems.

Electric vehicles, rely solely on the battery system for propulsion. The EVs have less maintenance than standard ICE vehicles. The Lithium Ion battery and motor do not typically require maintenance, there are fewer if no fluids to change. In general there are less moving parts than in ICE vehicles. 
In light of the overall less maintenance required with plug in vehicles dealerships make less profit on the sale of these vehicles. The National Automotive Dealerships Association (NADA) has stated that dealerships make three times the profit from maintenance and service than from new car vehicle sales. In addition, from a 2013 J.D. Power survey less than half (48\%) of electric vehicle buyers would go back to the dealership for service versus $57 \%$ of ICE vehicles.

In general electric vehicle sales are more complicated for sales staff and result in less profit over the life of the vehicle. An opportunity exists to increase dealership training and incentives to further electric vehicle deployment.

\subsection{Dealership Electrical Vehicle Supply Equipment \& Installation}

Several business models have been observed to be used by electrical vehicle manufacturers in the fulfilment of electrical vehicle infrastructure at dealerships. Each model impacts the experience of the key stakeholders and EV adoption.

\subsubsection{Turnkey model}

The turnkey model includes a single entity that provides electrical vehicle hardware, installation, customer service, training and overall program management. In the early stages of the EV deployment this was the preferred model for dealership electrical vehicle infrastructure installation. The costs and service of this model were transparent and key indicators such as product and installation cost, time to install and dealer satisfaction were measured.

\subsubsection{Third party fulfilment}

In this model, the automaker selects a retailer to fulfil the EVSE, conduct the site assessment and a separate company completes the installation. The manufacturer of the EVSE is often required to train both the $3^{\text {rd }}$ party retailer and also the contractor. The value of this model is familiarity of the consumer with the $3^{\text {rd }}$ party retailer. The downside of this model includes added cost, overhead and undefined roles and responsibilities of each stakeholder.

\subsubsection{Electrical Distribution}

The typical model used in most electrical devices is to have a single entity fulfil the electrical vehicle supply equipment, wiring, breakers, panel excess at a local electrical distributor (ED). The ED may hold local inventory, provide business terms and consolidate buying across multiple manufacturers. They typically are a one-stop shop for electrical contractors to fulfil project requirements at the dealership. This last model is now the most used within the industry. 


\section{Dealership Training}

To overcome a major hurdle in the adoption and optimisation of electrical vehicles, Leviton has developed a Dealership Outreach and Training program. The program enables the transfer of knowledge from the dealership to the consumer. In addition the program provides incentives for the dealerships to sell more electric vehicles. The program fosters an environment of learning and the value of electrical vehicle infrastructure. The program is currently being piloted in the New York market as part of NYSEDA PON 3016.

\subsection{Proposed Approach.}

Figure 1: $\quad$ Education and outreach of dealership is in four phases:

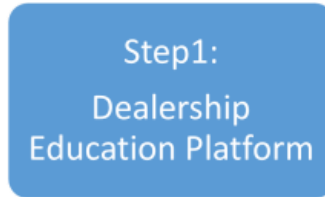

\section{Step 2:}

Program Exchange
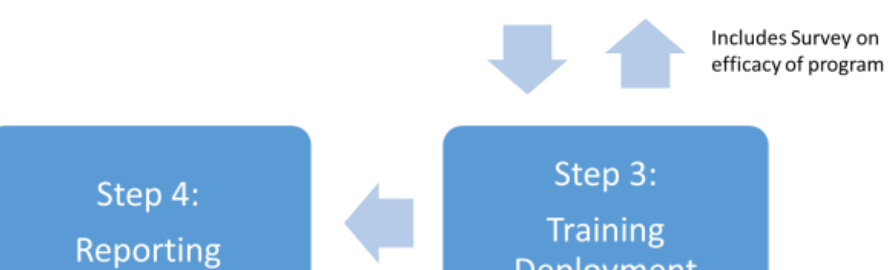

Reporting

\section{Step 3:}

Training

Deployment

\subsection{Education Platform and Program Exchange}

The education platform used for dealerships includes a multi-media approach. The primary training tools include online electrical vehicle content such as www.leviton.com/evrgreen and welcome kits which include video, product bulletins and information on local, state and federal incentives.

Figure 2: Example of Incentives:

\begin{tabular}{|c|c|c|c|c|c|c|c|}
\hline $\begin{array}{c}\text { State / } \\
\text { Province/ } \\
\text { Country }\end{array}$ & $\begin{array}{l}\text { Financial } \\
\text { Incentive }\end{array}$ & $\begin{array}{c}\text { Tax } \\
\text { Exemption }\end{array}$ & $\begin{array}{l}\text { Sales Tax } \\
\text { Credit }\end{array}$ & $\begin{array}{l}\text { Single } \\
\text { Occupancy } \\
\text { HOV Lane }\end{array}$ & $\begin{array}{l}\text { Parking } \\
\text { Incentive }\end{array}$ & $\begin{array}{l}\text { EVSE Tax } \\
\text { Credits }\end{array}$ & EVSE Rebate \\
\hline USA & $\begin{array}{l}\$ 7500 \text { Tax } \\
\text { Credit }\end{array}$ & & & & & Up to $30 \%$ & \\
\hline New York & & & & Yes & & Up to $50 \%$ & \\
\hline NewJersey & & Yes & & Yes & Yes & & \\
\hline Connecticut & 3000 & & & & $\begin{array}{c}\text { Yes (New } \\
\text { Haven) }\end{array}$ & & $\begin{array}{l}\text { Up to } \$ 10,000 \text { and } 6 \text { EVSEs for applicable } \\
\text { entrants. }\end{array}$ \\
\hline Massachusetts & 2500 & & & & & & $\begin{array}{l}\text { Fleet and Workplace grants. Fleet capped at } \\
\$ 6750 \text { (Private); } \$ 13,500 \text { (Public). }\end{array}$ \\
\hline Maryland & & & $\begin{array}{c}\text { Yes up to } \\
\$ 3000\end{array}$ & Yes & & & $\begin{array}{l}\$ 900 \text { for residential \& up to } \$ 7,500 \text { for } \\
\text { commercial charging stations. }\end{array}$ \\
\hline Quebec & $\begin{array}{l}\text { Up to } \\
\$ 8000\end{array}$ & & & Proposed & & & Up to $\$ 1000$ \\
\hline Ontario & $\begin{array}{l}\text { Up to } \\
\$ 14,000\end{array}$ & & & Yes & & & Yes, \$1000 \\
\hline
\end{tabular}


Select dealership were also provided collateral to be used at the showroom floor-include kiosks and signage. This may be the first time a consumer is exposed to electric vehicle infrastructure. The purpose of the kiosks or signage can improve the consumer experience through key messaging, phone numbers, websites and social media information.

Figure 3: Dealership Kiosk Examples:
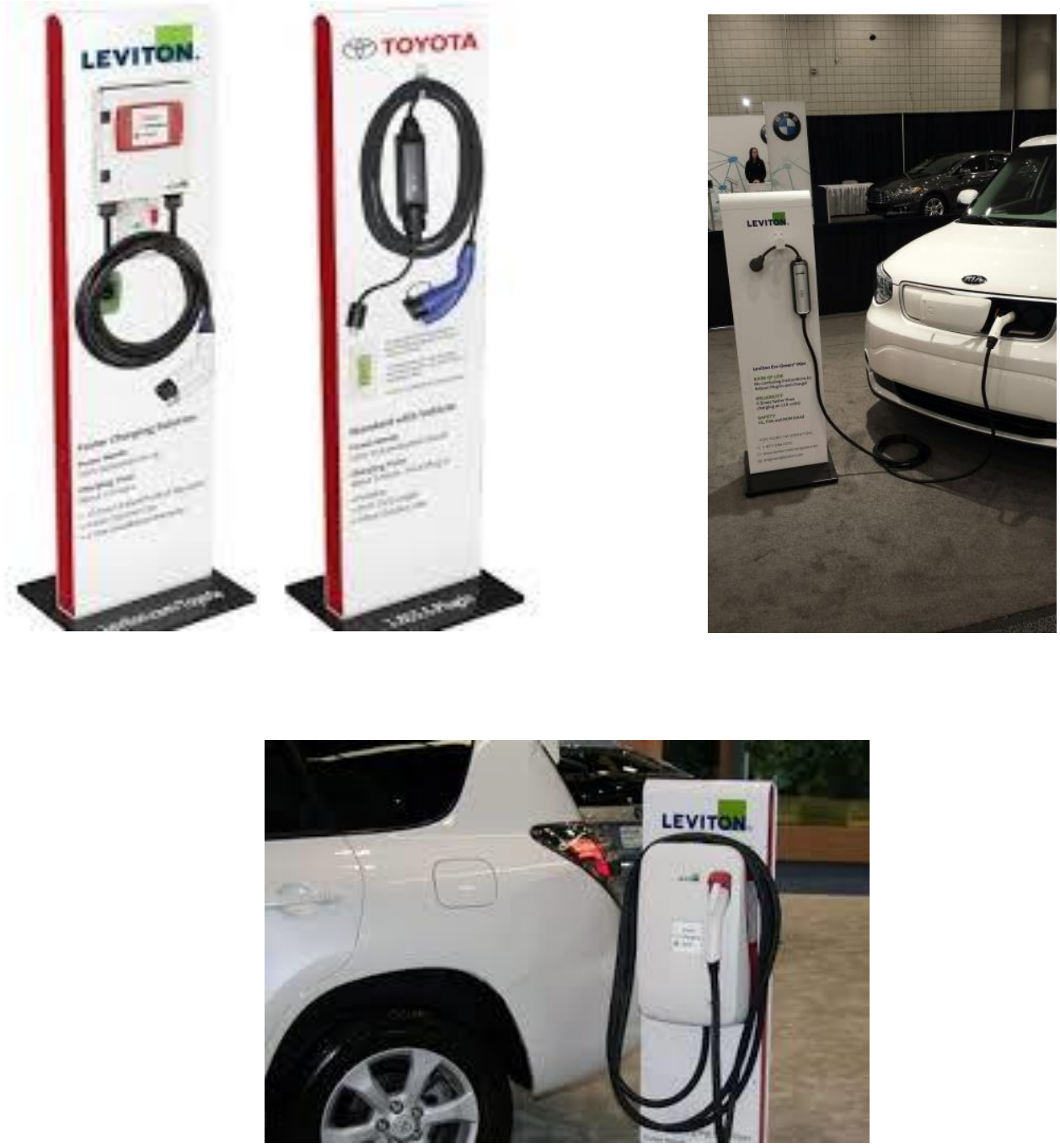

\subsection{Training Deployment and Reporting}

The training and deployment was conducted in three phases. The first phase was a pilot with small number of dealerships. The feedback developed through the first phase was used to update and refine the training materials. In phase 2 we sent communication via email and phone to a larger number of dealerships. In phase 3 we visited a number of dealerships onsite.

The dealership training concluded with a questionnaire to be completed by the sales associate or manager. A successful score of $80 \%$ or greater allows the recipient to receive a certification for their knowledge on plug in electric vehicle infrastructure. As a means to take action on the training material the matriculated dealership received a voucher towards $25 \%$ off the purchase of the electrical vehicle supply equipment. 
Following certification, the recipient will receive a survey on the training material (and trainers). This survey provides a "report card" enabling Leviton to utilize a 360 degree approach and further modify the training material if necessary.

Figure 4: Dealership Outreach Survey Example:

\section{LEVITON. \\ Security \& Automation Exit this survey \\ Dealership Outreach Training Survey}

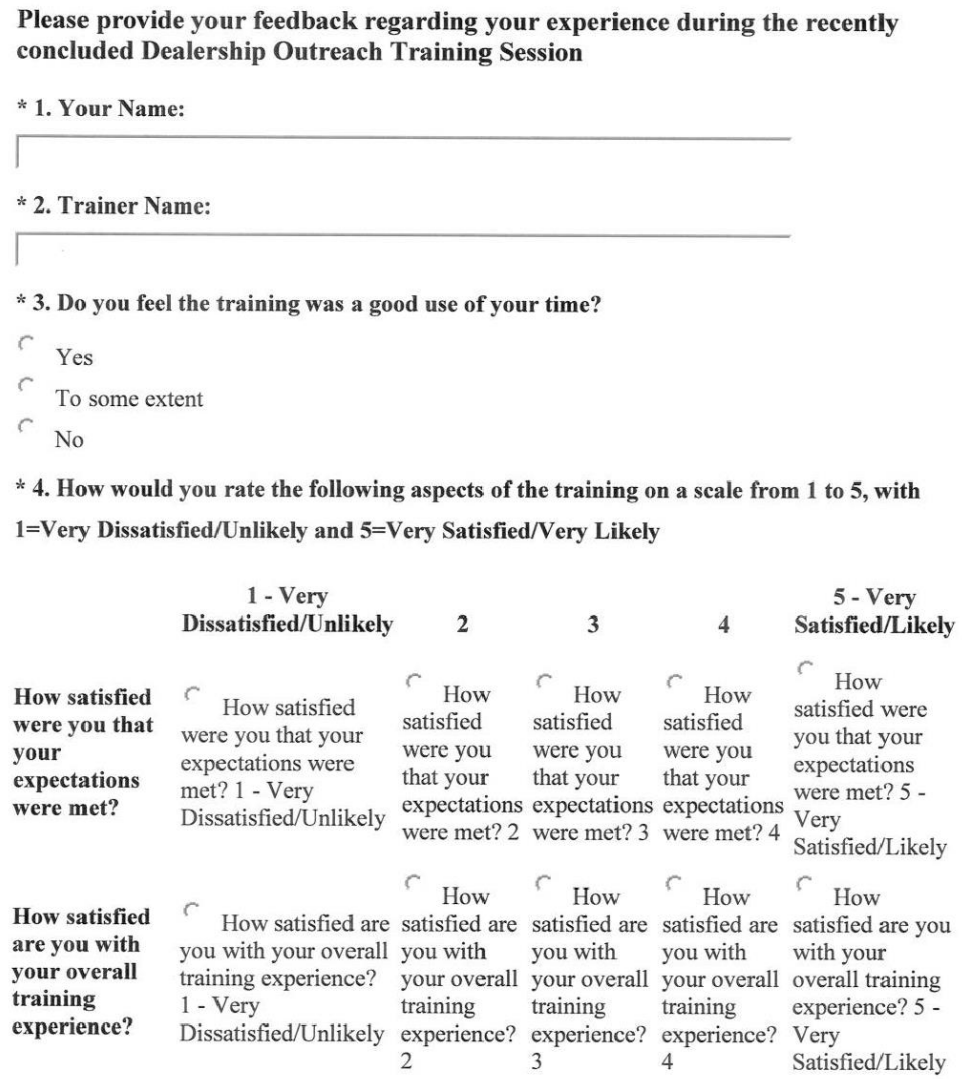

\section{Conclusions}

At the time of this paper submission, final project for dealership education and outreach is still underway.

Preliminary findings on the program is as follows:

- $\quad$ The most knowledgeable dealerships included those that had dealership management and sales staff using electric vehicles as their daily driver. The most engaged staff also had an EVSE to use at the dealership and at the dealer principles' home. Regular use of electric vehicles enabled the dealership staff to understand the value proposition of EVs and better communicate to potential consumers.

- Installation of electrical infrastructure should include the service area and front of dealership. The survey bay area was used to charge the electric vehicle after service. Many customers expect their electric vehicle to be charged after service, similar to a car wash. The charging infrastructure in front of the dealership should be valuable for consumers and other electric 
vehicle drivers. The infrastructure in front of the dealership can be used as a marketing tool to retain and attract new customers.

- Many dealership staff indicated they should have greater incentives for electric vehicles to compensate for lost service and maintenance and additional time for sales activity. Most dealerships would value an opportunity for a compensation (or spiff) for electric vehicle sales.

- Training for dealership staff on EVSEs needs to be an ongoing initiative. Training should include multimedia tools and simplified 1 page sales sheets that indicate EV fuel savings, local incentives and advantages of the EV.

- $\quad$ Ongoing communication is required for dealership on the cost of ownership. This could include EV incentives, local utility time of use programs, HOV lane access and consumer home Level 2 charger support.

- $\quad$ Many dealerships had different business models for home level 2 programs such as 1 . including an EVSE with each vehicle sale; 2. turnkey installation and EVSE; 3. preferred EVSEs with discounted pricing; 4. or Level 1 EVSE only. The preferred model for the dealership included compensation for the electric vehicle infrastructure transaction.

\section{Acknowledgments}

American Honda

Toyota Motor Sales

Kia Motors

New York State and Energy Authority

\section{References}

[1] Center for Sustainable Energy

[2] NYSERDA Public Opportunity for Notice 3016- Dealership Education and Outreach

[3] Edmunds.com, "Roles of the Car Dealership Sales Department Staff," August 2013

[4] NY Times, “A Car Dealers Won’t Sell: It’s Electric,” November 2015

[5] US Department of Energy, Alternative Fuels Data Center

\section{Authors}

Manoj Karwa is the Senior Director of Electrical Vehicle Supply Equipment programs for Leviton Manufacturing. His responsibilities include leading Leviton's global electrical vehicle supply business and developing business partnerships and acquisitions. Prior to joining Leviton, Manoj was managing partner at AP Bio-Consulting LLC and held senior positions at AT Kearney, Ricardo Consulting Engineers, Alcoa, Visteon and General Motors Corporation. Manoj's educational background includes advanced degrees in engineering and business from Carnegie Mellon University, Purdue University, Case Western Reserve and University of Michigan.

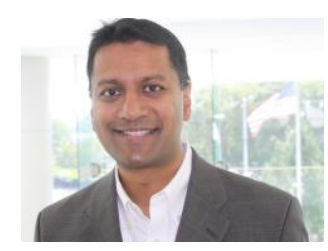

